\title{
Reducing lifelong disability from sports injuries in children
}

\author{
See also research article by Emery and colleagues on page 1249 and at www.cmaj.ca/lookup/doi/10.1503/cmaj.101540.
}

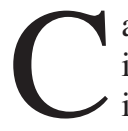

anadians admire their professional athletes, especially if they overcome adversity and continue to play while injured. These athletes are often role models for children and youth. However, imitating professional athletes by playing while injured comes with serious health and economic consequences. We should ask ourselves whether such practices on the hockey rink, soccer field or ski hill are worth the risk of long-term disability.

First, as parents, let us dispense with the fantasy that our children will become the next Sidney Crosby, David Beckham or Nancy Greene. Only about 500 Canadians play in the National Hockey League. ${ }^{1}$ Given our population of 32.5 million, that means only 16 of every 1 million Canadians play professional hockey at the top level. ${ }^{1}$ Similarly small proportions will achieve professional or Olympic success in other sports.

Second, let us consider the health and economic consequences. The annual incidence of catastrophic injury related to sports or recreation is 6.9 per 100000 participants, and a substantial proportion of those injured are athletes less than 21 years old. ${ }^{2}$ Each year, nearly 500 Ontarians are admitted to hospital because of a hockey-related injury, with thousands more seeking acute medical care. ${ }^{3}$ Children aged 1112 years who play in hockey leagues that allow bodychecking have more than a threefold increased risk of concussion or other injury. ${ }^{4}$ In youth hockey, concussions are underreported by team players and personnel: a maximum of 24.3 concussions per 1000 player game hours was estimated from a survey of non-elite male youth hockey players, as compared with a maximum of 0.61 per 1000 based on official injury reports. ${ }^{5}$ Repeated concussions can cause long-term disabilities that prevent return to play and have a lasting impact on the ability to function and enjoy life. ${ }^{6}$ The economic consequences of these injuries include the direct costs of care and indirect costs resulting from loss of future productivity, which are often much higher than direct costs when young people are involved.

Allowing a child or youth to return to the same game after an injury risks permanent damage, and it may even be career limiting for elite players hoping to be future professional or Olympic athletes. Injuries heal better and faster if they are protected from further insults during recovery. With concussions, preventing further trauma is crucial.

As a society, we hope to prepare young people for life events, including how to persevere through difficulties. However, we should not confuse excellence and bravery with behaviour that needlessly and unwisely causes long-term harm.

Whose responsibility is it to reduce lifelong disability from sports injuries in children and youth? Certainly it does not rest with professional athletes. Their livelihoods depend on taking risks. Similarly, sports commentators and the media have a vested interest in celebrating risk-taking behaviours and physical contact in sport because audiences love the spectacle.

What about parents? Even though protective instincts and bonds between parents and children are strong, so too are hopes and dreams. Some parents contribute to the problem by living vicariously through their children, seriously overestimating chances of elite amateur or professional success, and exhibiting unrestrained enthusiasm sometimes bordering on rage. Simply educating parents will probably not work.

Reducing lifelong disability from sports injuries in children and youth demands a public health solution similar to that used to combat smoking and drunk driving. A coordinated, multifaceted approach involving awareness, education and rule changes is required. Unnecessary risk taking and violent physical contact in sport need to be "de-normalized" through education and awareness campaigns. Getting sports organizations to change the rules is another solution. Parents who understand the problem and want their children to play with less risk can champion the cause. Former professional athletes whose careers were ended by major injuries can also help. The medical profession can contribute by providing evidence on what works in primary and secondary prevention of injury and by developing guidelines for practitioners and coaches on mandatory recovery times before allowing players to return to play. Finally, tracking rates and long-term consequences of sports injuries will be essential.

Children and youth can still be pushed to succeed in sports, but with fewer risks and less physical contact. The goal is not to change the behaviour and practices of professional and Olympic athletes. Rather, it is to keep our young players healthy to enjoy the rest of their lives. Unnecessary lifelong disability will not help anyone, least of all a minor who cannot fully appreciate the consequences of serious injury. Let's be careful not to excel at causing long-term harm rather than true sporting achievements.

\begin{abstract}
Alun D. Ackery MD MSc, Allan S. Detsky MD PhD; with the editorial advisory team: Paul C. Hébert MD MHSc, Matthew B. Stanbrook MD PhD, Ken Flegel MDCM MSc, Noni E. MacDonald MD MSc
\end{abstract}

For references, see Appendix 1, available at www.cmaj.ca/lookup/suppl /doi:10.1503/cmaj.110634/-/DCI

Competing interests: None declared by Alun Ackery or Allan Detsky. See www.cmaj.ca/site/misc/cmaj_staff.xhtml for editorial advisory team statements.

Affiliations: See www.cmaj.ca/site/misc/cmaj_staff.xhtml for editorial advisory team statements. Alun Ackery is with the Division of Emergency Medicine, Department of Medicine, University of Toronto, Toronto, Ont.; and Allan Detsky is with the Departments of Health Policy, Management and Evaluation, and Medicine, University of Toronto, and the Department of Medicine, Mount Sinai Hospital and University Health Network, Toronto, Ont.

Correspondence to: CMAJ editor, pubs@cmaj.ca

CMAJ 2011. DOI:10.1503/cmaj.110634 